\title{
Deposit Shedding in Biomass-Fired Boilers: Shear Adhesion Strength Measurements
}

Laxminarayan, Yashasvi; Jensen, Peter Arendt; Wu, Hao; Jappe Frandsen, Flemming; Sander, Bo; Glarborg, Peter

Published in:

Energy and Fuels

Link to article, DOI:

10.1021/acs.energyfuels.7b01312

Publication date:

2017

Document Version

Peer reviewed version

Link back to DTU Orbit

Citation $(A P A)$ :

Laxminarayan, Y., Jensen, P. A., Wu, H., Jappe Frandsen, F., Sander, B., \& Glarborg, P. (2017). Deposit Shedding in Biomass-Fired Boilers: Shear Adhesion Strength Measurements. Energy and Fuels, 31(8), 87338741. https://doi.org/10.1021/acs.energyfuels.7b01312

\section{General rights}

Copyright and moral rights for the publications made accessible in the public portal are retained by the authors and/or other copyright owners and it is a condition of accessing publications that users recognise and abide by the legal requirements associated with these rights.

- Users may download and print one copy of any publication from the public portal for the purpose of private study or research.

- You may not further distribute the material or use it for any profit-making activity or commercial gain

- You may freely distribute the URL identifying the publication in the public portal 


\section{Deposit Shedding in Biomass-fired Boilers: Shear}

\section{Adhesion Strength Measurements}

Yashasvi Laxminarayan* ${ }^{\dagger}$, Peter Arendt Jensen ${ }^{\dagger}$, Hao $\mathrm{Wu}^{\dagger}{ }^{\dagger}$, Flemming Jappe Frandsen ${ }^{\dagger}$, Bo Sander ${ }^{\S}$, Peter Glarborg ${ }^{\dagger}$

$\dagger$ Department of Chemical and Biochemical Engineering, Technical University of Denmark, Søltofts Plads 229, 2800 Kgs. Lyngby, Denmark

§ DONG Energy A/S, Kraftsværksvej 53, Skærbæk, DK-7000, Fredericia, Denmark

Keywords: biomass, ash, boiler, adhesion strength, shedding, sintering

*Corresponding author e-mail id: ylax@kt.dtu.dk

Abstract: Ash deposition on boiler surfaces is a major problem encountered in biomass combustion. Timely removal of ash deposits is essential for optimal boiler operation. In order to improve the understanding of deposit shedding in boilers, this study investigates the adhesion strength of biomass ash from full-scale boilers, as well as model fly ash deposits containing $\mathrm{KCl}$, $\mathrm{K}_{2} \mathrm{SO}_{4}, \mathrm{CaO}, \mathrm{CaSO}_{4}, \mathrm{SiO}_{2}, \mathrm{~K}_{2} \mathrm{CO}_{3}, \mathrm{Fe}_{2} \mathrm{O}_{3}, \mathrm{~K}_{2} \mathrm{Si}_{4} \mathrm{O}_{9}$ and $\mathrm{KOH}$. Artificial biomass ash deposits were prepared on superheater tubes, and sintered in an oven with temperatures ranging from $500^{\circ} \mathrm{C}$ to $1000^{\circ} \mathrm{C}$. Subsequently, the deposits were sheared off by an electrically controlled arm, and the corresponding adhesion strength was measured. The effect of sintering temperature, sintering time, deposit composition, thermal shocks on the deposit and steel type was investigated. The results 
reveal that adhesion strength of ash deposits is dependent on two factors: ash melt fraction, and corrosion occurring at the deposit-tube interface. Adhesion strength increases with increasing sintering temperature, sharply increasing at the ash deformation temperature. However, sintering time, as well as the type of steel used, does not have a significant effect under the investigated conditions. Addition of compounds which increase the melt fraction of the ash deposit, typically by forming a eutectic system, increases the adhesion strength, whereas addition of inert compounds with a high melting point decreases the adhesion strength. Furthermore, the study indicated that sulphation of ash deposits leads to an increase in adhesion strength, while cooling down the deposits after sintering decreases the adhesion strength. Finally, it was observed that adhesion strength data follows a log-normal distribution.

\section{Introduction}

One of the major operational problems encountered in biomass-fired boilers is the formation of ash deposits on boiler surfaces. Ash deposition hinders the efficiency of heat transfer to the steam cycle $^{1}$ and may completely block flue gas channels in severe cases, causing expensive unscheduled boiler shutdowns. Furthermore, ash deposits may cause severe corrosion of boiler surfaces. ${ }^{2}$ Therefore, timely and effective removal of ash deposits is essential for optimal boiler operation.

Natural as well as artificially induced shedding of ash deposits may be caused by several mechanisms including erosion, debonding, molten slag flow, and thermal and mechanical stresses in the deposits. ${ }^{3}$ Full-scale investigations have revealed that debonding is the dominant mechanism for shedding of dense and hard deposits in biomass boilers, ${ }^{4}$ occurring when the generated stress (e.g. by soot-blowing or due to the inherent weight of the deposit) exceeds the adhesion strength at the deposit-tube interface. ${ }^{1}$ Hence, quantification of the adhesion strength of ash deposits is crucial for understanding deposit shedding, and for optimizing artificial removal of deposits (e.g. 
by soot-blowing or application of thermal shocks). Sootblowing in boilers produces both lateral (lift) and longitudinal (drag) forces on deposits, ${ }^{5}$ highlighting the importance of understanding the shear as well as tensile adhesion strength of ash deposits. Additionally, the adhesion strength at the interface is dependent on the contact area between the steel tube and the innermost layer of the ash deposit. ${ }^{5}$ The innermost layer of biomass ash deposits is primarily formed by heterogeneous condensation, or homogeneous/heterogeneous nucleation and subsequent thermophoretic deposition of alkali salts, ${ }^{6,7}$ with their composition typically dominated by $\mathrm{KCl}$ and $\mathrm{K}_{2} \mathrm{SO}_{4} .{ }^{8}$

Previous studies have investigated the adhesion strength of deposits for coal ash ${ }^{9-11}$ as well as ash from kraft recovery boilers. ${ }^{5}$ Other studies have tried to quantify the inherent compression and bend strength of sintered ash deposits. ${ }^{12-16}$ However, there is a lack of understanding of the adhesion strength of biomass ash deposits to boiler surfaces. The literature lacks a detailed investigation, describing the effect of various parameters, such as sintering temperature, chemical composition and sintering time, on the adhesion strength of biomass ash deposits.

The present work quantifies the shear adhesion strength of biomass ash and salt rich deposits in a laboratory oven, in order to determine the effect of gas and steel surface temperature, deposit chemical composition, sintering duration, steel type and thermal shocks brought about by a rapid change in sintering temperature. The study simulates the conditions present at the deposit-tube interface, under different deposit properties and boiler conditions. Apart from providing a better fundamental understanding of deposit shedding, the outcome of this study may facilitate boiler operation by recommending boiler conditions for minimizing the formation of strong deposits. Furthermore, the data obtained from this study may be used to optimize soot-blowing in boilers.

\section{Experimental Section}




\section{$\underline{\text { Materials }}$}

Experimental analysis was carried out using fly ash obtained from the electrostatic precipitator / bag filter of a straw-fired grate boiler (Avedøreværket unit 2, $100 \mathrm{MW}_{\text {th }}$ ), a wood-fired suspension boiler (Avedøreværket unit 2, $800 \mathrm{MW}_{\text {th }}$ ), and a straw + wood co-fired suspension boiler (Amagerværket unit 1, $350 \mathrm{MW}_{\text {th }}$ ). The fly ash properties are provided in Table 1 . While the straw fly ash is rich in $\mathrm{K}$ and $\mathrm{Cl}$, the wood fly ash and the straw + wood co-fired fly ash are rich in $\mathrm{Ca}$ and $\mathrm{Si}$. As a result, the ash deformation temperature, ${ }^{17}$ which is the temperature at which the ash first softens and therefore becomes sticky, ${ }^{18}$ of straw fly ash is low $\left(640^{\circ} \mathrm{C}\right)$, whereas the ash deformation temperature of wood fly ash and straw + wood co-fired fly ash is rather high $\left(1240^{\circ} \mathrm{C}\right.$ and $1220^{\circ} \mathrm{C}$ ). Additionally, model fly ash deposits were prepared using mixtures of $\mathrm{KCl}$ (Sigma Aldrich, CAS number: 7447-40-7), $\mathrm{K}_{2} \mathrm{SO}_{4}$ (Sigma Aldrich, CAS number: 7778-80-5), $\mathrm{K}_{2} \mathrm{CO}_{3}$ (Sigma Aldrich, CAS number: 584-08-7), $\mathrm{CaO}$ (Sigma Aldrich, CAS number: 1305-78-8), $\mathrm{CaSO}_{4}$ (Alfa Aesar, CAS number: 7778-18-9), $\mathrm{SiO}_{2}$ (Sigma Aldrich, CAS number: 60676-86-0), $\mathrm{Fe}_{2} \mathrm{O}_{3}$ (Sigma Aldrich, CAS number: 1309-37-1), $\mathrm{K}_{2} \mathrm{Si}_{4} \mathrm{O}_{9}$ (Alfa Aesar, CAS number: 1312-76-1) and KOH (Sigma Aldrich, CAS number: 1310-58-3), in order to understand the effect of different components constituting a typical biomass fly ash. The melting point / eutectic point / glass transition temperature of the model fly ash compounds is provided in Table 2. Each of the different components was milled and sieved individually to obtain a particle size distribution bounded by $32 \mu \mathrm{m}$ and $90 \mu \mathrm{m}$. However, it should be noted that fly ash in boilers typically form a bimodal particle size distribution, consisting of sub-micron particles, as well as larger particles ( $\sim 10 \mu \mathrm{m}$ $200 \mu \mathrm{m})^{1,6}$. Although the deposits prepared in this study do not contain any sub-micron particles, it is ensured that the particle size lies within the second peak of the characteristic bimodal size 
distribution. Since $\mathrm{KCl}$ and $\mathrm{K}_{2} \mathrm{SO}_{4}$ are the major species found in the inner layer of typical biomass ash deposits, ${ }^{8}$ all investigated model fly ash deposits contained $\mathrm{KCl}$ and $\mathrm{K}_{2} \mathrm{SO}_{4}$.

Experiments were carried out using 3 different types of steel, TP347HFG (Salzgitter Mannesmann), 316SS (Sandvik) and 3R69BT (Sandvik), as well as tubes made from pure iron. The tubes had an outer diameter of $38 \mathrm{~mm}$, and a thickness of $5 \mathrm{~mm}$. The chemical composition of the steel tubes is provided in Table 3. The addition of $\mathrm{Cr}$, Mo and $\mathrm{Mn}$ in steel reduces oxide scale growth, ${ }^{19,20}$ improving overall corrosion resistance, ${ }^{21}$ while $\mathrm{Ni}$ acts as a deterrent for $\mathrm{Cl}$ induced corrosion. ${ }^{22}$ Pre-oxidation of steel tubes is beneficial for hindering corrosion, ${ }^{23,24}$ and provides superior replication of operational boiler tubes. ${ }^{25,26}$ Thermogravimetric analysis of the steel tubes at $600^{\circ} \mathrm{C}$ revealed that majority of the oxidation occurs in first few hours, after which the rate of oxidation significantly slows down (see Figure 1). Therefore, the tubes were preoxidized for 24 hours at $600^{\circ} \mathrm{C}$ prior to conducting experiments.

\section{Sample preparation}

In order to obtain tightly packed and adherent deposits, the ash particles were mixed with a $50 \%$ isopropanol solution to prepare a thick slurry, and molded into a cubical shaped deposit on the surface of the tube, using a Teflon mold (see Figure 2). The deposits were $15 \mathrm{~mm} \times 15 \mathrm{~mm} \times 10$ $\mathrm{mm},(\mathrm{WxDxH})$ in size, leading to a contact surface area of $223 \mathrm{~mm}^{2}$. The use of deposit slurries is in accordance with EU guidelines ${ }^{2,27,28}$ for high temperature corrosion testing, providing a better representation of deposits in power plants. However, it should be noted that the deposit formation process and the typical particle size distribution of fly ash in boilers is different from the samples prepared in this study. ${ }^{1,6,8}$

Deposit sintering and adhesion strength measurement 
The deposits were heated up and sintered inside an oven for a fixed duration. A purge air flow of $15 \mathrm{NL} / \mathrm{min}$ was injected into the oven, to protect the oven heating elements from corrosion.

After sintering, the deposits were cooled down to the required measurement temperature at a rate of $15^{\circ} \mathrm{C} / \mathrm{min}$, subsequently followed by shear adhesion strength measurements. An electrically controlled arm was used to de-bond the artificial ash deposit from the superheater tube, as shown in Figure 2. The arm was controlled using a linear actuator, and the corresponding force applied on the ash deposit was measured using a load cell. Shear adhesion strength was calculated by dividing the measured force by the contact area between the deposit and the superheater tube. Standard experiments were performed by sintering the deposits at $650^{\circ} \mathrm{C}$ for 4 hours, while the adhesion strength was measured at $600^{\circ} \mathrm{C}$. These parameters were chosen providing consideration to typical sintering temperatures of the inner layers of the deposit, ${ }^{8}$ typical boiler steam temperatures, ${ }^{29-32}$ temperature gradients across the steel tube, resulting in the steel surface temperature to be $20^{\circ} \mathrm{C}-50^{\circ} \mathrm{C}$ higher than the steam temperature,,$^{8,33,34}$ reasonable experimental time and the deposit formation process. ${ }^{6,31}$ In order to account for the scatter observed while measuring adhesion strength, measurements were conducted on at least 4 deposit samples for each instance of experimental conditions.

Selected samples were analyzed using Scanning Electron Microscopy to observe the deposittube interface. The steel tubes, along with deposits, were cast in epoxy and polished, without any exposure to water, thereby preventing any dissolution, recrystallization and removal of salts.

\section{Results and Discussion}

\section{$\underline{\text { Effect of sintering temperature }}$}


Figure 3 shows the effect of sintering temperature on adhesion strength. Experiments were performed with pure $\mathrm{KCl}$, as well as three different boiler fly ashes (see Table 1). It can be observed that adhesion strength increases with increasing temperature, with a sharp increase near the melting point / ash deformation temperature, ${ }^{17}$ i.e., $640^{\circ} \mathrm{C}$ for straw fly ash, and $770^{\circ} \mathrm{C}$ for $\mathrm{KCl}$.

A sharp increase in adhesion strengths for wood fly ash and the straw + wood co-fired fly ash has not been observed in this study, due to their high ash deformation temperatures, $1220^{\circ} \mathrm{C}$ and $1240^{\circ} \mathrm{C}$ respectively (see Figure 3). Furthermore, it should be noted that increasing the temperature of the oven to temperatures significantly higher than the melting point (or ash deformation temperature) led to completely molten deposits, whose adhesion strength could not be measured.

\section{Effect of eutecticity}

The constituents of fly ash typically form eutectic systems, ${ }^{3,35}$ leading to melt formation at temperatures lower than the melting point of the individual components. The aforementioned results seem to indicate that the adhesion strength of an ash deposit is dependent on its melting point. Previous studies in literature have indicated that the melt fraction of the deposit, especially at the deposit-tube interface, influences its adhesion strength. ${ }^{4,5}$ In order to better understand this phenomenon, experiments were performed with model fly ash compounds containing $\mathrm{KCl}$ and $\mathrm{K}_{2} \mathrm{SO}_{4} . \mathrm{KCl}$ and $\mathrm{K}_{2} \mathrm{SO}_{4}$, with individual melting points of $770^{\circ} \mathrm{C}$ and $1069^{\circ} \mathrm{C}$, form a eutectic system with a eutectic temperature of $690^{\circ} \mathrm{C}$. The eutectic temperature was calculated using the software, FactSage. ${ }^{36,37}$ However, other experimental studies have identified melt formation at $683^{\circ} \mathrm{C}$ for a $50 \mathrm{wt} . \% \mathrm{KCl}-\mathrm{K}_{2} \mathrm{SO}_{4}$ system. ${ }^{38} \mathrm{In}$ the experiments, the amount of $\mathrm{K}_{2} \mathrm{SO}_{4}$ in $\mathrm{KCl}$ was varied at $650^{\circ} \mathrm{C}$, and the corresponding results are shown in Figure 4, along with the $\mathrm{KCl}_{2}-\mathrm{K}_{2} \mathrm{SO}_{4}$ phase diagram. The phase diagram was obtained using FactSage. 
The results indicate that while pure substances do not have much adhesion strength at $650^{\circ} \mathrm{C}$, mixing of the components causes a large increase in the adhesion strength. Since $\mathrm{KCl}$ and $\mathrm{K}_{2} \mathrm{SO}_{4}$ form a eutectic system, mixing of the two components leads to an increase in the melt fraction of the deposit. Therefore, it can be inferred that a higher melt fraction at the deposit-tube interface leads to a higher adhesion strength. However, the experiments were carried out at $650^{\circ} \mathrm{C}$, which is lower than the eutectic temperature of the $\mathrm{KCl}-\mathrm{K}_{2} \mathrm{SO}_{4}$ system. This indicates the presence of a secondary phenomenon influencing deposit adhesion strength, which has been explored in the following section by conducting a SEM analysis of the deposit-tube interface.

\section{SEM analysis of the deposit-tube interface}

In order to determine the morphology of the deposits at the deposit-tube interface, SEM analysis of the interface was carried out for the model fly ash deposit containing $\mathrm{KCl}$ and $\mathrm{K}_{2} \mathrm{SO}_{4}$ (50 wt.\%). The analysis revealed the formation of a dense, partially molten layer at the interface, as seen in Figure 5. As the temperature increases, corrosion starts to occur at the interface. As a result, corrosion products, such as Fe/Cr chlorides, oxides, chromates, etc., are formed. ${ }^{2,39-43}$ Most of the corrosion products form a complex eutectic system with the components present in the deposit. ${ }^{44,45}$ This leads to a lower eutectic temperature at the interface, compared to the outer layers of the deposit. The partially molten layer causes increased surface wetting and adsorption, ${ }^{46}$ leading to high surface adhesion.

It should be noted that debonding always occurred in the corrosion layer throughout all experiments, exposing a fresh layer of steel tube after deposit removal.

\section{Effect of composition}


Experiments were conducted with model fly ash deposits to understand the role of different components present in a typical biomass fly ash. The model fly ash deposits were made up of particles larger than $32 \mu \mathrm{m}$ and smaller than $90 \mu \mathrm{m}$.

The results highlight the effect of sulphation on adhesion strength, as seen in Figure 6 . The deposit containing $\mathrm{KCl}$ and $\mathrm{K}_{2} \mathrm{SO}_{4}$ (50 wt.\%) exhibited much higher adhesion strength compared to a deposit containing pure $\mathrm{KCl}$. Similarly, the deposit containing $\mathrm{KCl}, \mathrm{K}_{2} \mathrm{SO}_{4}$ and $\mathrm{CaSO}_{4}(33$ wt.\% each) showed a higher adhesion strength than the deposit containing $\mathrm{KCl}, \mathrm{K}_{2} \mathrm{SO}_{4}$ and $\mathrm{CaO}$.

The increase in adhesion strength of deposits containing sulphur can be attributed to the fact that $\mathrm{KCl}-\mathrm{K}_{2} \mathrm{SO}_{4}$ and $\mathrm{KCl}-\mathrm{K}_{2} \mathrm{SO}_{4}-\mathrm{CaSO}_{4}$ form a eutectic system (see Table 2). Therefore, sulphation lowers the eutectic/deformation temperature of the ash deposit, increasing melt fraction, and thereby increasing adhesion strength.

In boilers, $\mathrm{KCl}$ can undergo sulphation in the gas phase prior to deposition, ${ }^{47}$ or in solid phase after deposition on boiler surfaces. ${ }^{48}$ While gas phase sulphation is faster than solid phase sulphation, the deposit is exposed to the flue gas for a longer period of time,${ }^{48}$ making both sulphation mechanisms relevant. Similarly, $\mathrm{CaO}$ can undergo sulphation to form $\mathrm{CaSO}_{4} \cdot{ }^{49,50}$

Sulphation of $\mathrm{KCl}$ in deposits can occur as a gas-solid or gas-liquid reaction by $\mathrm{SO}_{2}{ }^{51}$ or $\mathrm{SO}_{3},{ }^{52}$ as shown in the following equations.

$2 \mathrm{KCl}+\mathrm{SO}_{2}+1 / 2 \mathrm{O}_{2}+\mathrm{H}_{2} \mathrm{O} \rightarrow \mathrm{K}_{2} \mathrm{SO}_{4}+2 \mathrm{HCl}$

$2 \mathrm{KCl}+\mathrm{SO}_{3}+\mathrm{H}_{2} \mathrm{O} \rightarrow \mathrm{K}_{2} \mathrm{SO}_{4}+2 \mathrm{HCl}$

Iron oxide may catalytically convert $\mathrm{SO}_{2}$ to $\mathrm{SO}_{3},{ }^{45,53}$ or react with $\mathrm{SO}_{2}$ to form $\mathrm{Fe}(\mathrm{III})$ sulphites or sulphates, ${ }^{54,55}$ thereby catalyzing the overall sulphation reaction and increasing the concentration of $\mathrm{K}_{2} \mathrm{SO}_{4}$ near the steel surface.

The present results provide evidence that sulphation may result in an increase in adhesion strength at the investigated conditions. However, these results are not conclusive, since sulphate- 
forming reactions occurring inside the deposit have not been explored in the conducted experiments. Further investigation of deposit sulphation is required to completely understand the influence of the overall sulphation process on deposit adhesion strength. Nevertheless, it is speculated that reactions occurring between the deposit and the flue gas may contribute to adhesion strength variations in boilers.

Furthermore, the results portray the effect of $\mathrm{CaO}, \mathrm{SiO}_{2}, \mathrm{~K}_{2} \mathrm{CO}_{3}, \mathrm{Fe}_{2} \mathrm{O}_{3}, \mathrm{~K}_{2} \mathrm{Si}_{4} \mathrm{O}_{9}$ and $\mathrm{KOH}$ (see Figure 6). While $\mathrm{Ca}$ and $\mathrm{Si}$ are widely present in biomass ash deposits, the presence of $\mathrm{K}_{2} \mathrm{CO}_{3}$ has been identified in only a few studies in literature. ${ }^{56,57}$ The addition of $\mathrm{CaO}$ to a model fly ash deposit containing $\mathrm{KCl}-\mathrm{K}_{2} \mathrm{SO}_{4}$ decreased its adhesion strength. $\mathrm{CaO}$ does not form a eutectic melt with the $\mathrm{KCl}-\mathrm{K}_{2} \mathrm{SO}_{4}$ system, effectively reducing the melt fraction, and thereby decreasing the adhesion strength. However, the addition of $\mathrm{SiO}_{2}$ does not seem to significantly affect the adhesion strength under the conditions examined.

The addition of $\mathrm{K}_{2} \mathrm{CO}_{3}$ to the model fly ash deposit containing $\mathrm{KCl}$ and $\mathrm{K}_{2} \mathrm{SO}_{4}$ considerably increased the adhesion strength. Addition of $\mathrm{K}_{2} \mathrm{CO}_{3}$ decreases the eutectic temperature of the $\mathrm{KCl}-$ $\mathrm{K}_{2} \mathrm{SO}_{4}$ system (see Table 2), increasing the melt fraction of the ash deposit at $650^{\circ} \mathrm{C}$, and thereby increasing the adhesion strength. Furthermore, $\mathrm{K}_{2} \mathrm{CO}_{3}$ may react with the steel, leading to the formation of a potassium-chromium compound, most likely $\mathrm{K}_{2} \mathrm{CrO}_{4},{ }^{41,58,59}$ which forms a lowtemperature melt with $\mathrm{KCl}^{60}{ }^{60}$ further increasing the melt fraction at the deposit-tube interface.

Moreover, the addition of $\mathrm{Fe}_{2} \mathrm{O}_{3}$ significantly increased the adhesion strength of the ash deposits, bolstering the aforementioned theory correlating corrosion with high adhesion strength. Apart from decreasing the melting point of the mixture (see Table 2), presence of $\mathrm{Fe}_{2} \mathrm{O}_{3}$ in the deposit may cause increased formation of corrosion intermediates, such as $\mathrm{FeCl}_{2}$ or $\mathrm{FeCl}_{3}$, according to the following proposed reaction. The reaction mechanism has been verified using Factsage. ${ }^{37}$ 


$$
\mathrm{Fe}_{2} \mathrm{O}_{3}+6 \mathrm{KCl} \rightleftharpoons 2 \mathrm{FeCl}_{3}+3 \mathrm{~K}_{2} \mathrm{O}
$$

Moreover, in full-scale boilers, where $\mathrm{HCl}$ present in the flue gas may be oxidized to $\mathrm{Cl}_{2}$, the following reaction may occur, leading to the formation of $\mathrm{FeCl}_{2}{ }^{22,61,62}$

$$
\mathrm{Fe}_{2} \mathrm{O}_{3}+2 \mathrm{Cl}_{2} \rightleftharpoons 2 \mathrm{FeCl}_{2}+1.5 \mathrm{O}_{2}
$$

Since $\mathrm{FeCl}_{2}$, as well as $\mathrm{FeCl}_{3}$, forms a eutectic system with the ash deposit, the corresponding increase in melt fraction results in an increase in adhesion strength.

A similar increase in adhesion strength is observed when $\mathrm{K}_{2} \mathrm{Si}_{4} \mathrm{O}_{9}$ is added to the $\mathrm{KCl}-\mathrm{K}_{2} \mathrm{SO}_{4}$ system. The presence of alkali silicates has been identified in mature and sintered deposits in strawfired boilers. ${ }^{8} \mathrm{~K}_{2} \mathrm{Si}_{4} \mathrm{O}_{9}$ is known to form a glass phase at high temperatures, gradually decreasing in viscosity with increasing temperature. ${ }^{63}$ Analysis of the $\mathrm{K}_{2} \mathrm{Si}_{4} \mathrm{O}_{9}$ samples using Differential Scanning Calorimetry revealed that $\mathrm{K}_{2} \mathrm{Si}_{4} \mathrm{O}_{9}$ has a glass transition temperature of $650^{\circ} \mathrm{C}$ (see Figure 7). The formation of a semi-molten glass phase causes an increase in surface wetting and increased adhesion of the deposit to the steel tube.

The presence of $\mathrm{KOH}$ in deposits has been postulated in a few studies in literature. ${ }^{56,62}$ In the present study, it was observed that even the addition of a small amount of $\mathrm{KOH}(2.5 \mathrm{wt} . \%)$ to the model fly ash deposit causes a large increase in adhesion strength. This can directly be attributed to the low melting point of $\mathrm{KOH}\left(360^{\circ} \mathrm{C}\right)$ and the formation of a eutectic system with $\mathrm{KCl}-\mathrm{K}_{2} \mathrm{SO}_{4}$ (see Table 2), causing increased melt formation and adhesion strength.

From this section, it can be concluded that addition of compounds which increase the melt fraction of the ash deposit, usually by forming a eutectic system, increases the adhesion strength. However, addition of inert compounds with a high melting point, such as $\mathrm{CaO}$ (melting point of $2572^{\circ} \mathrm{C}$ ), decreases the adhesion strength.

\section{Effect of sintering time}


Sintering time seems to have a negligible effect on adhesion strength up to 24 hours at the investigated conditions, as seen in Figure 8. It should be noted that the all experiments are subjected to an additional 30 minutes of heating time prior to sintering, and 5 minutes for strength measurement after sintering.

The results suggest that the initial, partially molten corrosion layer is formed rather quickly, and significant changes in adhesion strength do not occur after the formation of the initial corrosion layer at the interface within 24 hours. Several studies in literature indicate that the onset of corrosion is typically within a few minutes, and the rate of corrosion decreases exponentially over time. ${ }^{2,39,64}$ The marginal change in melt fraction due to increasing corrosion is not significant enough to observe reliable changes in adhesion strength. However, further investigation is required prior to arriving at conclusions, especially considering that sintering in boilers may occur for longer durations.

Nevertheless, an increase in deposit adhesion strength may be observed in boilers due to sintering caused by reactions occurring in the deposit, e.g., sulphation, ${ }^{65}$ which have not been investigated in this study. Sulphation does not occur in the experimental setup, due to the absence of $\mathrm{SO}_{2}$ in the gas stream.

\section{Effect of thermal shocks}

Application of thermal shocks to induce deposit shedding is a technique commonly used to remove heavily sintered deposits from superheater tubes. ${ }^{13,66}$ This study further investigates the effect of thermal shocks by cooling down the deposit after sintering. Deposits were cooled down at a rate of $15^{\circ} \mathrm{C} / \mathrm{min}$.

As seen in Figure 9, cooling down the deposits results in a decrease in adhesion strength. Thermal stresses are induced at the deposit-tube interface, owing to differences in the thermal 
expansion coefficients between the deposit/corrosion layer and the steel tube ${ }^{66}$ As a result, cracks may develop at the interface, leading to a decrease in adhesion strength.

\section{Effect of steel type}

In order to understand the effect of the type of steel used, experiments were carried out using a model fly ash deposit containing $\mathrm{KCl}-\mathrm{K}_{2} \mathrm{SO}_{4}(50 \mathrm{wt} . \%)$ on 3 different types of steel as well as pure iron tubes. Experiments were carried out for 4 hours at $650^{\circ} \mathrm{C}$.

The results indicate that the type of steel used does not have a strong influence on the adhesion strength at the investigated conditions, considering the scatter in data (see Figure 10). Previous studies have shown that $\mathrm{KCl}$ induces corrosion at the steel surface, irrespective of the type of steel, ${ }^{58}$ although the depth of the corrosion layer might be different. The results seem to indicate that while the presence of corrosion causes high adhesion strength, the depth of the corrosion layer is not a major factor influencing adhesion strength, especially considering that the onset of the

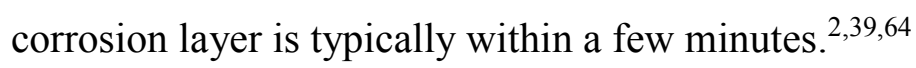

However, the adhesion strength of deposits to pure iron tubes appears to be slightly higher, when compared to the investigated steels, indicating that the presence of corrosion inhibiting elements in steel might play a role in influencing adhesion strength. Further investigation, spanning over a larger range of steel types, is required prior to arriving at conclusions.

\section{Analysis of scatter in adhesion strength data}

In order to better understand the significant scatter observed in the data, 24 experiments were conducted using $\mathrm{KCl}-\mathrm{K}_{2} \mathrm{SO}_{4}(50$ wt.\%) deposits. The experiments reveal that adhesion strength data roughly follows a log-normal distribution, as seen in Figure 11. This is similar to observations made using deposits from kraft recovery boilers. ${ }^{5}$ Moreover, experiments conducted in full-scale biomass-fired boilers indicate similar trends. ${ }^{4}$ 
The stochastic nature of debonding has significant implications on deposit shedding in boilers. The results suggest that even though soot-blowing may remove the majority of the deposits, the strongly adherent deposits might not be removed. Subsequent accumulation of strong deposits probably results in the eventual fouling of boiler surfaces. ${ }^{5}$

The adhesion strength of biomass ash deposits observed in this study is comparable in magnitude to coal ash deposits from lab-scale investigations, ${ }^{9-11}$ as well as biomass ash deposits from fullscale studies, ${ }^{4}$ as shown in Table 4 . However, previous lab-scale investigations indicate that deposits from kraft recovery boilers are more strongly adherent, when compared to biomass and coal ash deposits. ${ }^{5}$

\section{Practical application of the study}

The results allow better understanding of the process of deposit shedding, both qualitatively and quantitatively. Furthermore, the obtained data may be used to develop a tool for analyzing the effect of fuel composition on adhesion strength, and suggesting boiler operating conditions to prevent the formation of strong deposits. For example, the study identifies that maintaining steel temperatures below the ash deformation temperature results in the formation of weaker deposits. Furthermore, the study quantifies the degree of thermal shocks needed to weaken the strongly adherent deposits. Moreover, the study analyzes the effect of composition of the fly ash, which could be used to estimate fuel quality. However, further work is required prior to arriving at conclusions.

Additionally, the obtained data may be used to optimize soot-blowing in boilers by recommending soot-blowing frequencies and pressures based on the fuel and operating conditions. This may be done by modelling the log-normal distribution of adhesion strength data, 
incorporating the effect of deposit composition, flue gas temperature and steam temperature. However, further experimental work is required for the development of a detailed model.

\section{Conclusions}

This study investigated the shear adhesion strength of biomass ash deposits from full-scale boilers, as well as model fly ash deposits containing $\mathrm{KCl}, \mathrm{K}_{2} \mathrm{SO}_{4}, \mathrm{CaO}, \mathrm{CaSO}_{4}, \mathrm{SiO}_{2}, \mathrm{~K}_{2} \mathrm{CO}_{3}$, $\mathrm{Fe}_{2} \mathrm{O}_{3}, \mathrm{~K}_{2} \mathrm{Si}_{4} \mathrm{O}_{9}$ and $\mathrm{KOH}$. Deposits were prepared on superheater tubes, and sintered in a laboratory oven. The effect of sintering temperature, sintering time, deposit composition, thermal shocks on the deposit and steel type was investigated.

Increasing sintering temperatures resulted in higher adhesion strengths, with a sharp increase observed near the ash deformation temperature / melting point. Sintering time did not significantly affect adhesion strengths up to 24 hours at $650^{\circ} \mathrm{C}$, using a model fly ash deposit containing $\mathrm{KCl}-$ $\mathrm{K}_{2} \mathrm{SO}_{4}$ (50 wt.\%). Furthermore, it was substantiated that cooling down the deposit after sintering reduces the adhesion strength, due to thermal stresses induced at the deposit-tube interface.

Deposits containing sulphates showed increased adhesion strengths, indicating that sulphation may cause the formation of stronger deposits. The addition of $\mathrm{K}_{2} \mathrm{CO}_{3}, \mathrm{Fe}_{2} \mathrm{O}_{3}, \mathrm{~K}_{2} \mathrm{Si}_{4} \mathrm{O}_{9}$ and $\mathrm{KOH}$ to the model fly ash deposit increased the ash melt fraction at the deposit-tube interface, thereby increasing the adhesion strength, whereas the addition of $\mathrm{CaO}$ decreased the ash melt fraction, thereby decreasing the adhesion strength.

Furthermore, the type of steel used did not seem to have a considerable effect on the adhesion strength. Finally, experiments revealed that adhesion strength data roughly follows a log-normal distribution. 
This study identified that adhesion strength of ash deposits is dependent on two factors: ash melt fraction, and corrosion occurring at the deposit-tube interface. A higher ash melt fraction at the deposit-tube interface leads to an increase in adhesion strength. Corrosion occurring at the interface leads to the formation of corrosion products, which form a eutectic system with the inner layer of deposit and increase the local melt fraction, thereby increasing the adhesion strength. 


\section{FIGURES}

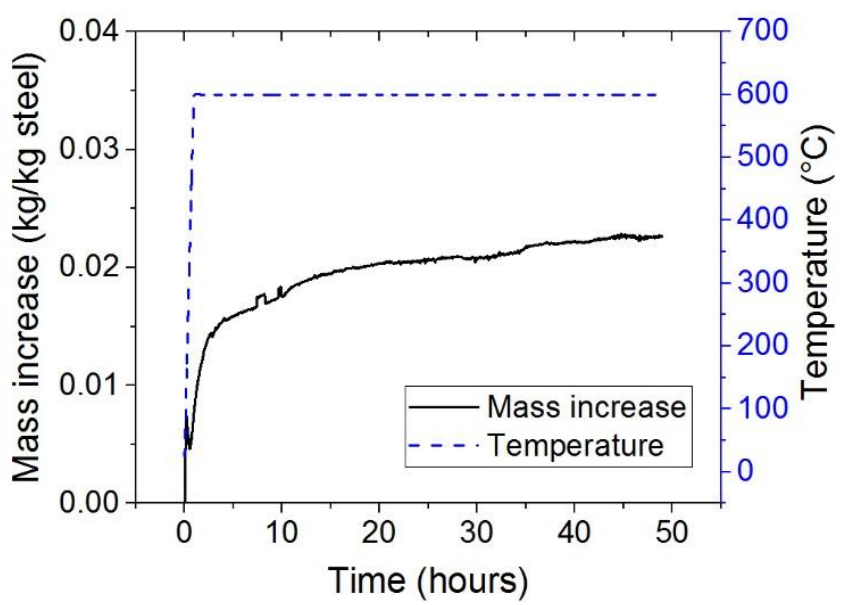

Figure 1. Thermogravimetric analysis of steel used (TP347HFG) exposed to air at $600^{\circ} \mathrm{C}$. Most of the oxidation occurs within the first few hours, after which the oxidation rate significantly slows down. Sample mass of $2059 \mathrm{mg}$, heating rate of $10 \mathrm{~K} / \mathrm{min}$.

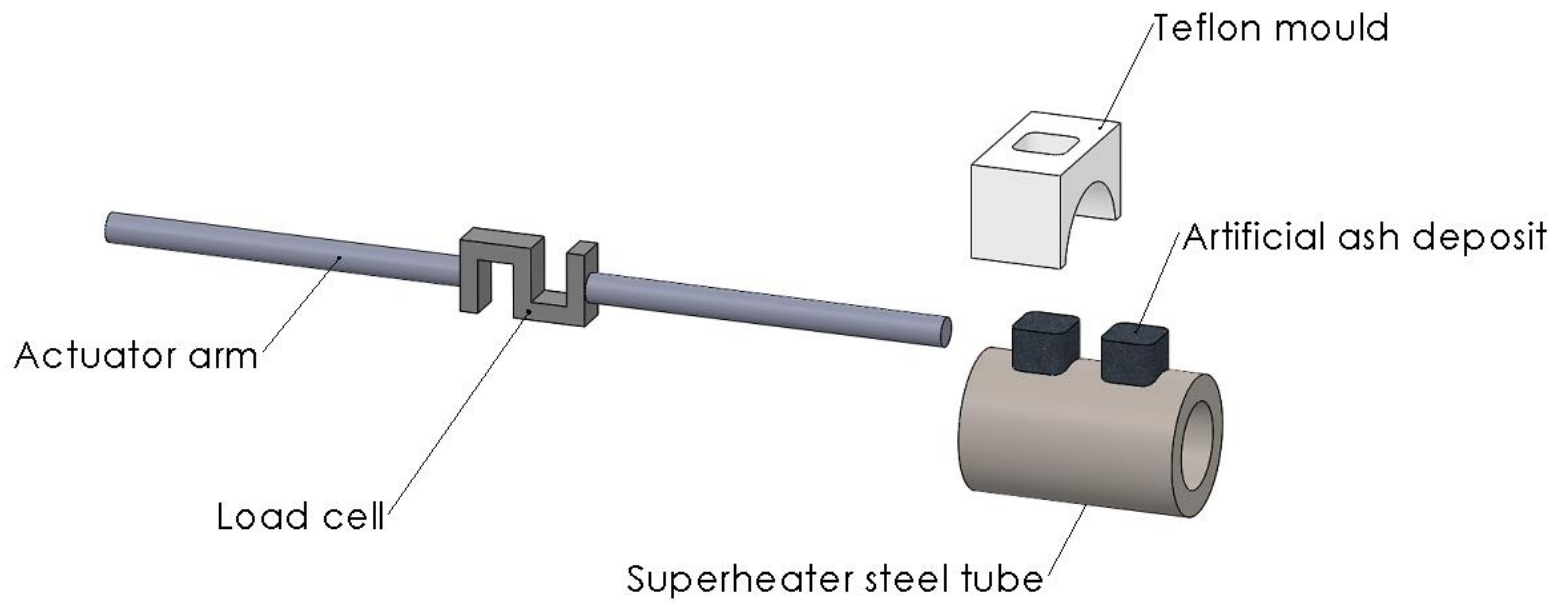

Figure 2. Experimental setup for adhesion strength measurements. The superheater steel tube is placed inside the oven while the load cell is outside the oven. The actuator arm shears off the artificial ash deposit and the load cell measures the corresponding adhesion strength. Image not to scale. 


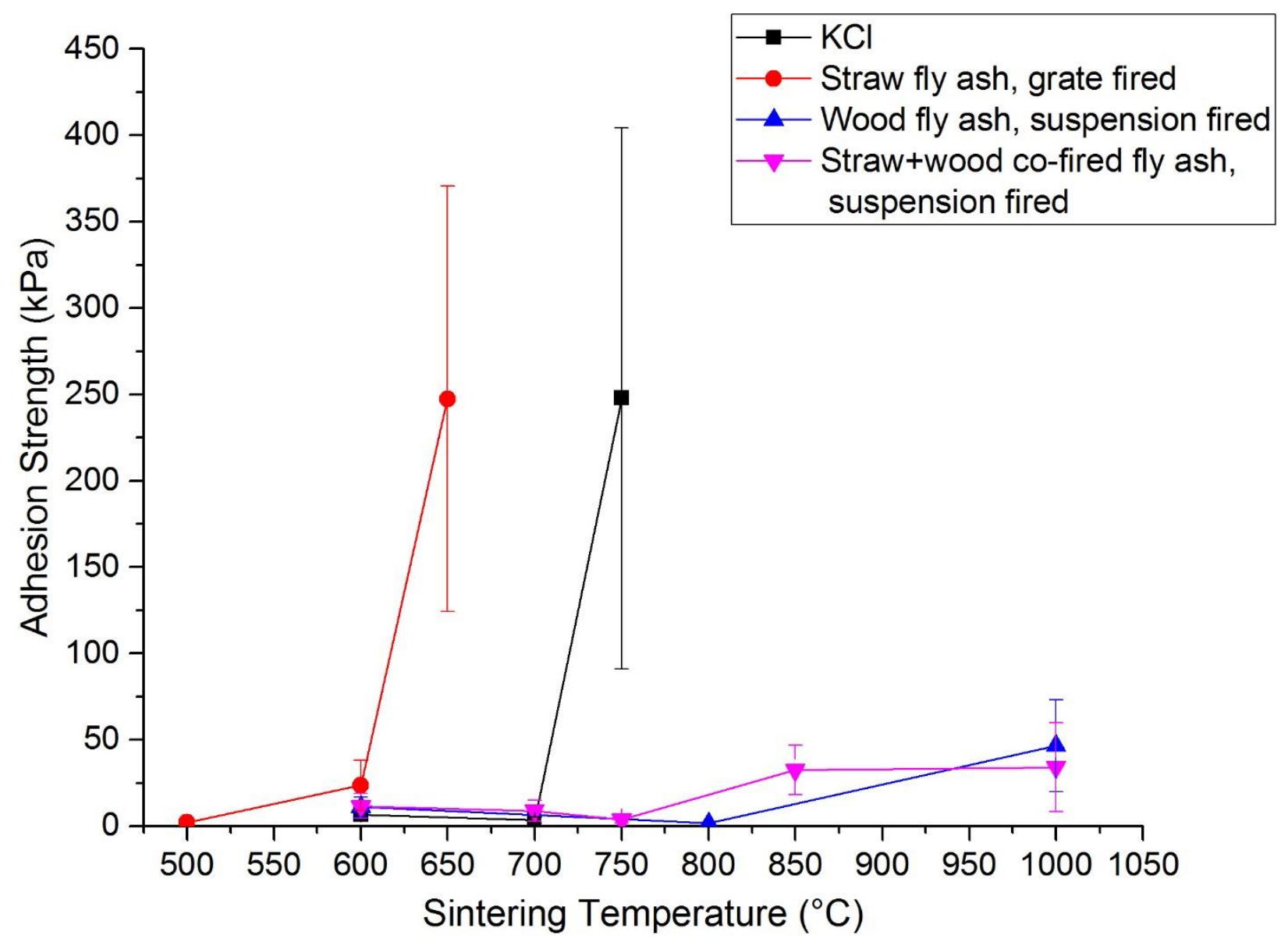

Figure 3. Effect of sintering temperature on shear adhesion strength for $\mathrm{KCl}$ and biomass fly ashes. Shear adhesion strength increases sharply near the melting point / ash deformation temperature. ${ }^{17}$ Deposits sintered for 4 hours, measured at $600^{\circ} \mathrm{C}$, TP347HFG steel pre-oxidized for 24 hours, average of 4 data points. 


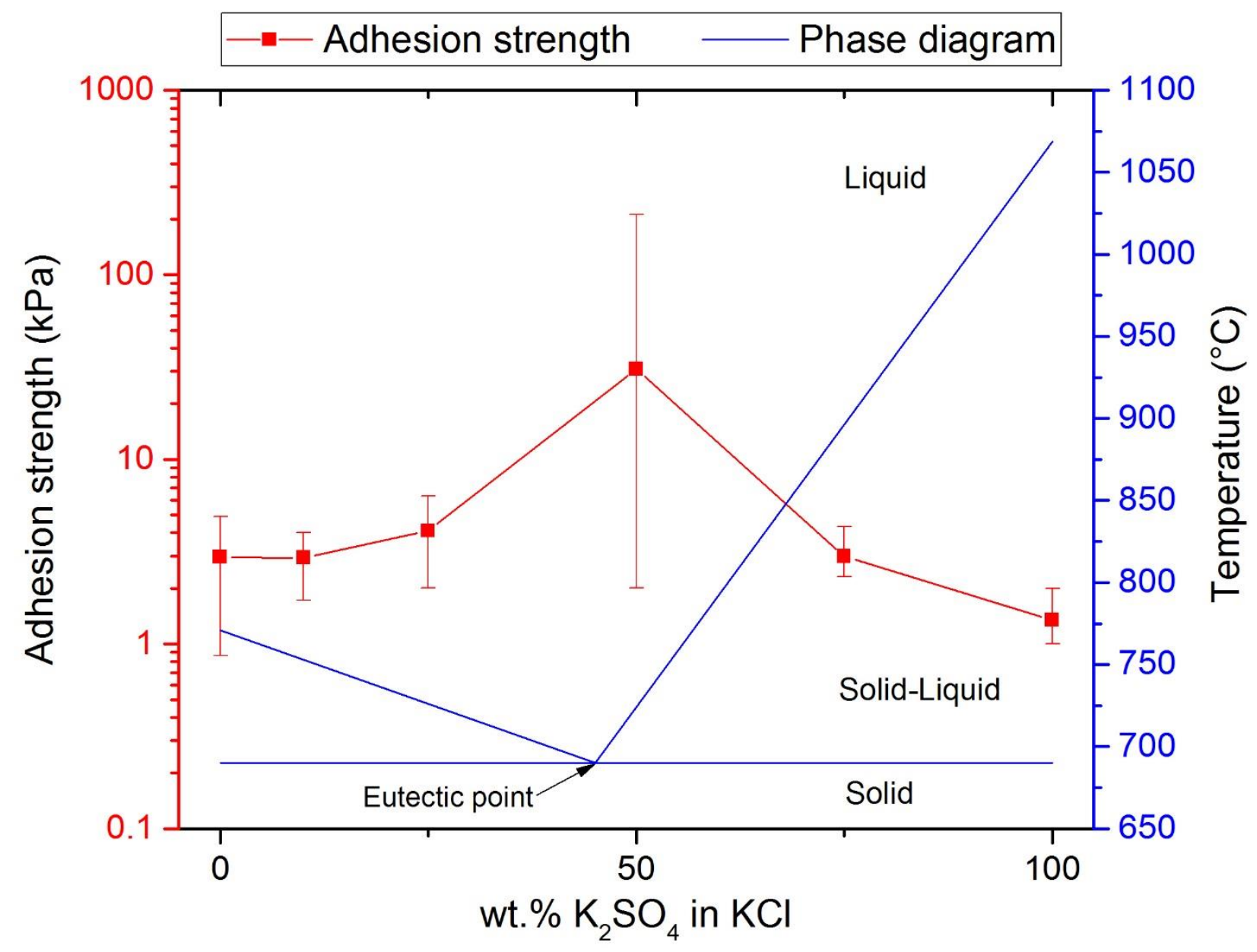

Figure 4. Effect of varying concentration of $\mathrm{K}_{2} \mathrm{SO}_{4}$ in $\mathrm{KCl}$ on shear adhesion strength. Deposits sintered at $650^{\circ} \mathrm{C}$ for 4 hours, measured at $600^{\circ} \mathrm{C}$, TP347HFG steel pre-oxidized for 24 hours, average of 4 data points ( 24 for $50 \mathrm{wt} . \%$ ). Mixing of $\mathrm{KCl}$ and $\mathrm{K}_{2} \mathrm{SO}_{4}$ causes an increase in adhesion strength. 


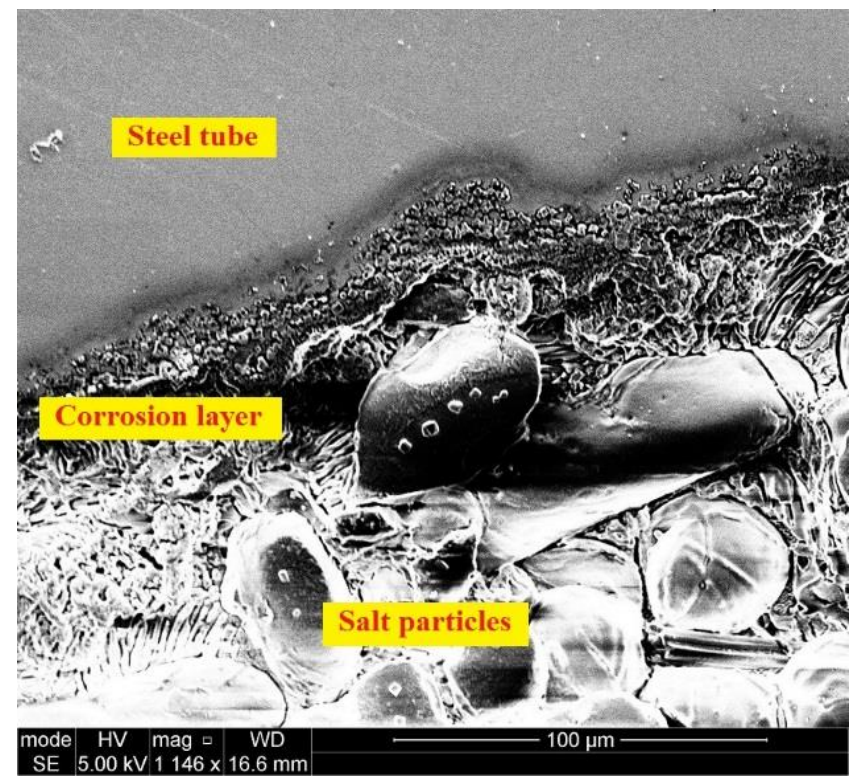

Figure 5. SEM image of deposit-tube interface. $\mathrm{KCl}-\mathrm{K}_{2} \mathrm{SO}_{4}(50 \mathrm{wt} . \%)$ deposit, sintered at $650^{\circ} \mathrm{C}$ for 4 hours, TP347HFG steel pre-oxidized for 24 hours. Partially molten corrosion layer observed at the deposit-tube interface. 


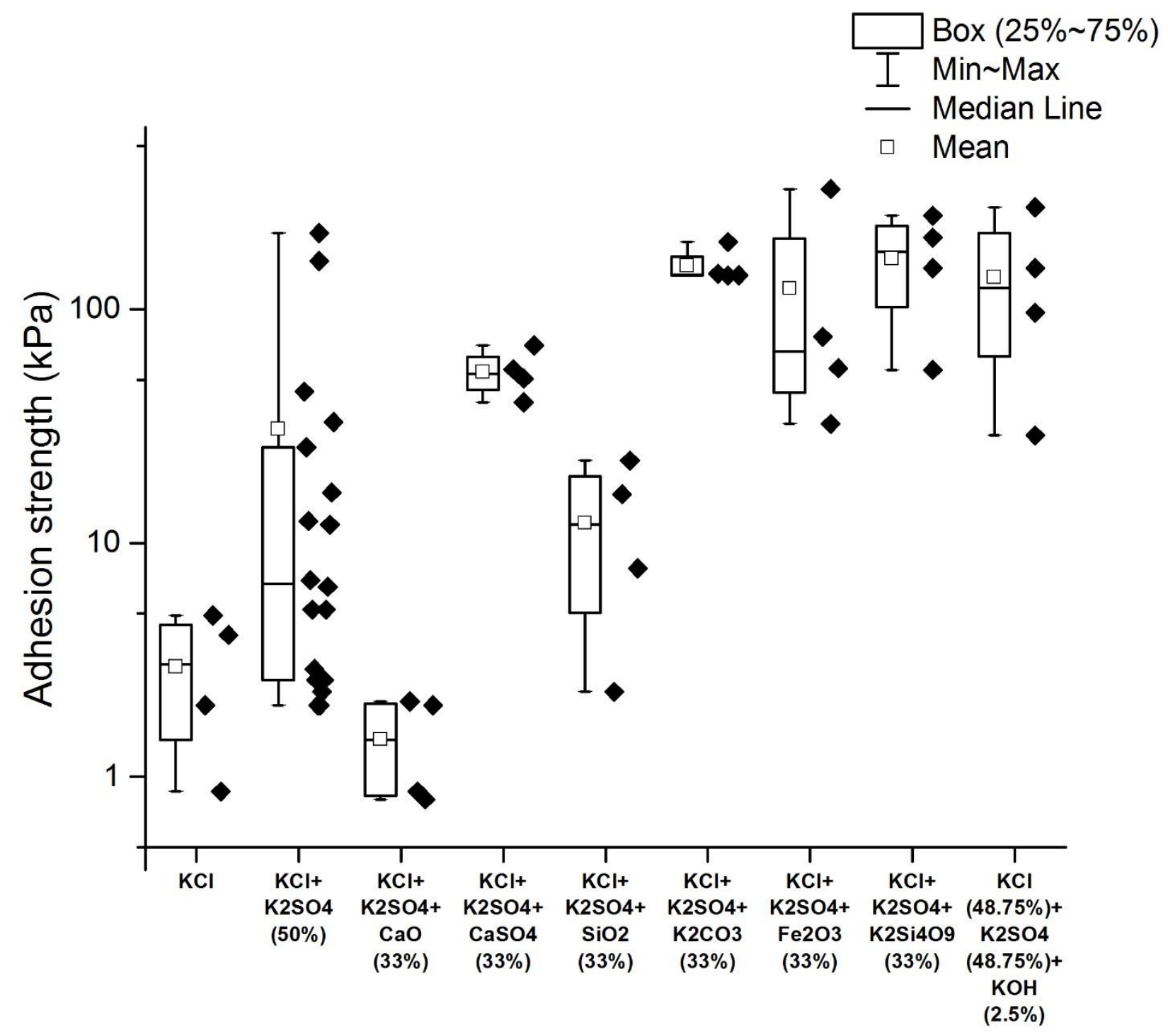

Figure 6. Effect of composition on adhesion strength using model fly ash compounds. Deposits sintered at $650^{\circ} \mathrm{C}$ for 4 hours, measured at $600^{\circ} \mathrm{C}$, TP347HFG steel pre-oxidized for 24 hours, 4 data points $\left(24\right.$ for $\left.\mathrm{KCl}+\mathrm{K}_{2} \mathrm{SO}_{4}\right)$. All compositions in weight $\%$. 


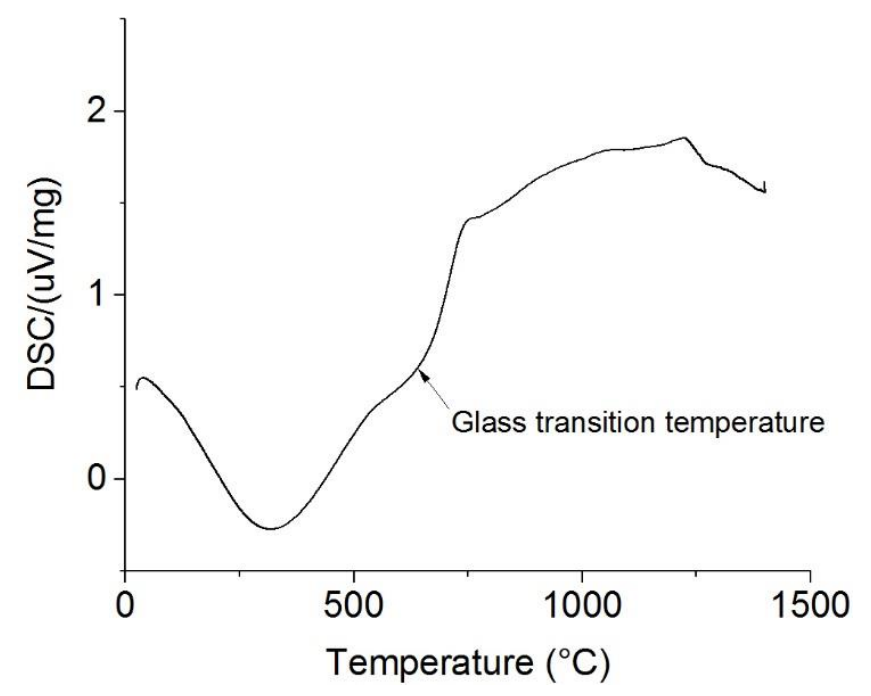

Figure 7. Differential Scanning Calorimetry analysis of $\mathrm{K}_{2} \mathrm{Si}_{4} \mathrm{O}_{9}$. The silicate forms a glassy phase, with a glass transition temperature of $650^{\circ} \mathrm{C}$. Sample mass of $10.5 \mathrm{mg}$, heating rate of 10 $\mathrm{K} / \mathrm{min}$.

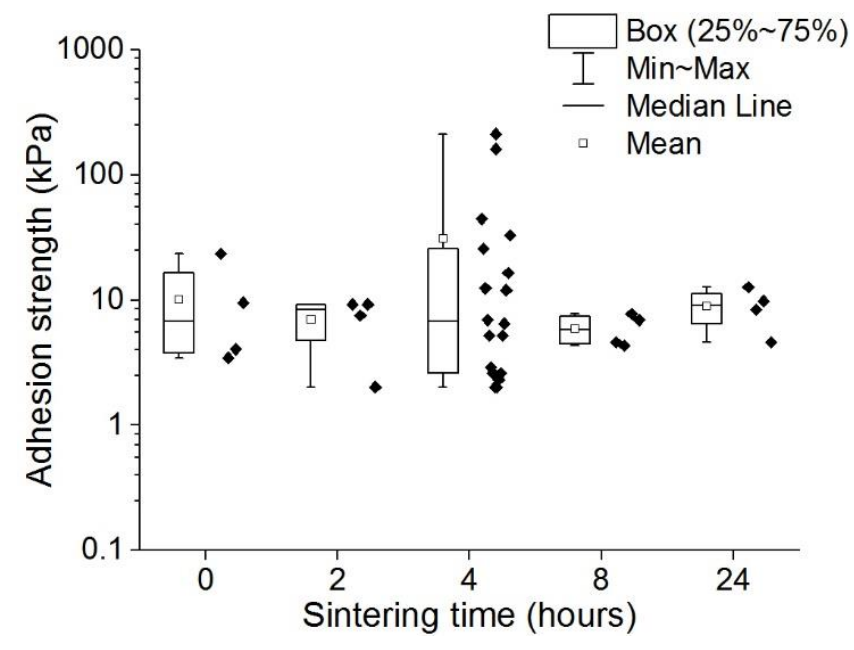

Figure 8. Effect of sintering time on adhesion strength. $\mathrm{KCl}-\mathrm{K}_{2} \mathrm{SO}_{4}(50 \mathrm{wt} . \%)$ deposit, sintered at $650^{\circ} \mathrm{C}$, measured at $600^{\circ} \mathrm{C}$, TP347HFG steel pre-oxidized for 24 hours, 4 data points (24 for 4 hours). 


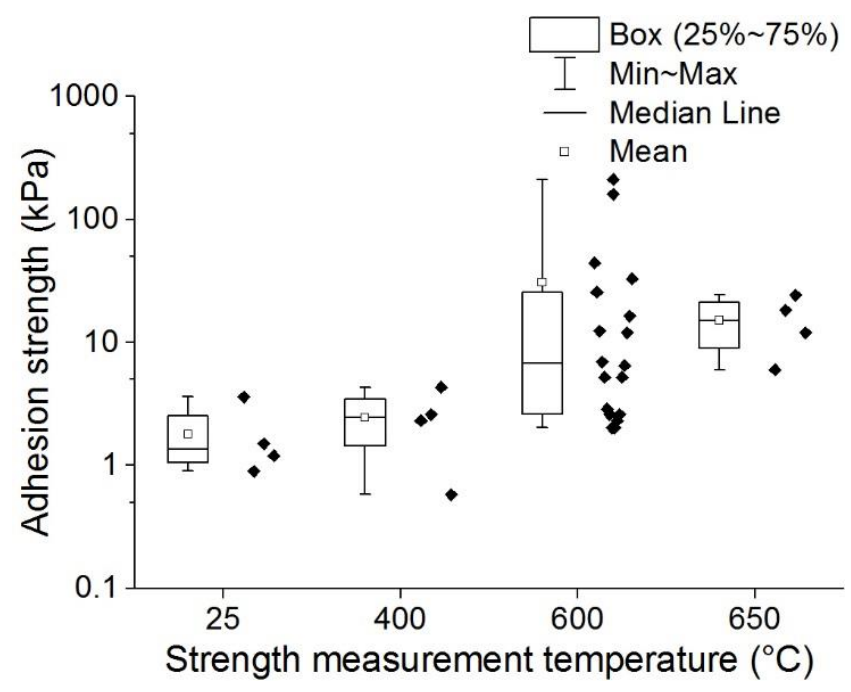

Figure 9. Effect of strength measurement temperature on adhesion strength. $\mathrm{KCl}-\mathrm{K}_{2} \mathrm{SO}_{4}(50 \mathrm{wt} . \%)$ deposit, sintered at $650^{\circ} \mathrm{C}$ for 4 hours, TP347HFG steel pre-oxidized for 24 hours, 4 data points $\left(24\right.$ for $\left.600^{\circ} \mathrm{C}\right)$

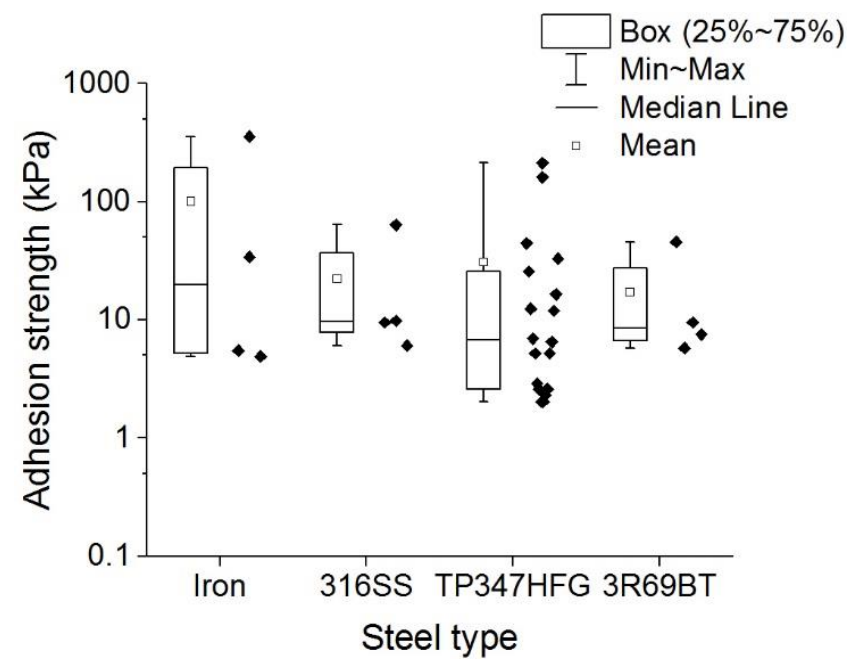

Figure 10. Effect of steel type on adhesion strength. $\mathrm{KCl}-\mathrm{K}_{2} \mathrm{SO}_{4}(50 \mathrm{wt} . \%)$ deposit, sintered at $650^{\circ} \mathrm{C}$ for 4 hours, measured at $600^{\circ} \mathrm{C}$, steels pre-oxidized for 24 hours, 4 data points ( 24 for TP347HFG) 


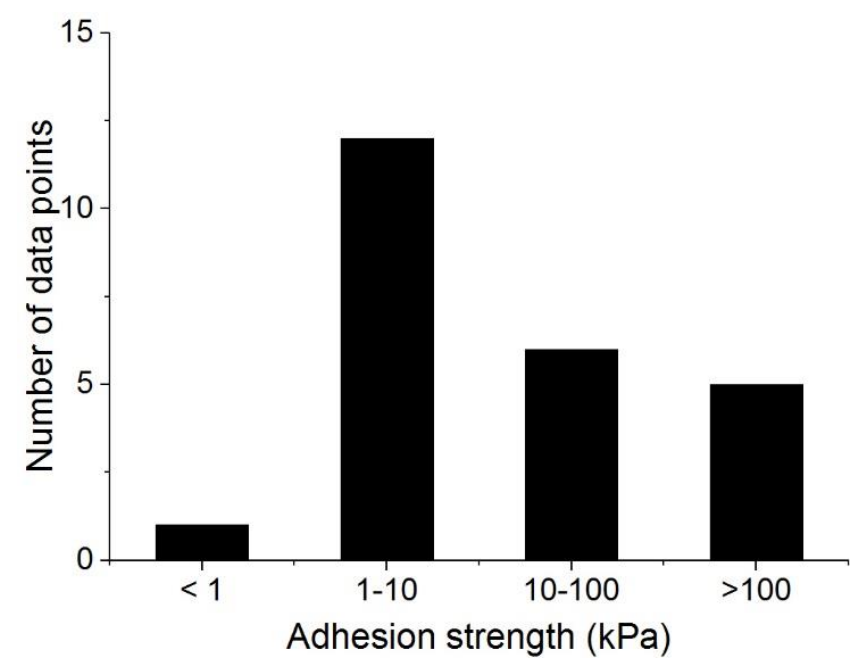

Figure 11. Log-normal distribution of adhesion strength data. $\mathrm{KCl}-\mathrm{K}_{2} \mathrm{SO}_{4}(50 \mathrm{wt} \%$ ) deposit, sintered at $650^{\circ} \mathrm{C}$ for 4 hours, measured at $600^{\circ} \mathrm{C}$, TP347HFG steel pre-oxidized for 24 hours, 24 data points 


\section{TABLES}

Table 1. Composition, particle size and melting point analysis of the investigated fly ashes

\begin{tabular}{|c|c|c|c|}
\hline $\begin{array}{l}\text { Elemental composition (wt. } \\
\% \text {, dry basis) }\end{array}$ & $\begin{array}{l}\text { Straw fly ash, } \\
\text { grate fired }\end{array}$ & $\begin{array}{l}\text { Straw + wood co- } \\
\text { fired fly ash, } \\
\text { suspension fired }\end{array}$ & $\begin{array}{l}\text { Wood fly ash, } \\
\text { suspension fired }\end{array}$ \\
\hline Al & - & 2 & 2.13 \\
\hline $\mathrm{Ca}$ & 1.3 & 20 & 20.8 \\
\hline $\mathrm{Cl}$ & 19 & 1.3 & 0.2 \\
\hline $\mathrm{Fe}$ & 0.044 & 1.4 & 1.73 \\
\hline $\mathrm{K}$ & 43 & 9.1 & 6.26 \\
\hline $\mathrm{Mg}$ & 0.12 & 3.3 & 3.22 \\
\hline $\mathrm{Na}$ & 0.9 & 0.9 & 0.43 \\
\hline $\mathrm{P}$ & - & 1.4 & 1.09 \\
\hline $\mathrm{S}$ & 7.9 & 1.5 & 1.08 \\
\hline $\mathrm{Si}$ & 1.1 & 12 & 17.7 \\
\hline $\mathrm{Ti}$ & - & 0.14 & - \\
\hline Mn & 0.059 & - & - \\
\hline Deformation temperature ${ }^{17}\left({ }^{\circ} \mathrm{C}\right)$ & 640 & 1240 & 1220 \\
\hline $\begin{array}{l}\text { Hemispherical temperature }{ }^{17} \\
\left({ }^{\circ} \mathrm{C}\right)\end{array}$ & 640 & 1250 & 1230 \\
\hline Fluid temperature ${ }^{17}\left({ }^{\circ} \mathrm{C}\right)$ & 760 & 1260 & 1240 \\
\hline Median particle size $(\mu \mathrm{m})$ & 51.7 & 44.5 & 34.7 \\
\hline
\end{tabular}


Table 2. Eutectic temperature / melting point / glass transition temperature of the investigated model fly ash compounds. Data obtained from multiple sources ${ }^{8,37,38,67}$

\begin{tabular}{|l|l|}
\hline Composition & $\begin{array}{l}\text { Eutectic } \\
\text { temperature } \\
\text { melting point } \\
\text { glass transition } \\
\text { temperature }\end{array}$ \\
\hline $\mathrm{KCl}$ & $\left.{ }^{\mathrm{b}} \mathbf{C}\right)$ \\
\hline $\mathrm{KCl}+\mathrm{K}_{2} \mathrm{SO}_{4}{ }^{\mathrm{a}}$ & 770 \\
\hline $\mathrm{KCl}+\mathrm{K}_{2} \mathrm{SO}_{4}+\mathrm{CaO}^{\mathrm{a}}$ & 690 \\
\hline $\mathrm{KCl}+\mathrm{K}_{2} \mathrm{SO}_{4}+\mathrm{CaSO}_{4}{ }^{\mathrm{a}}$ & 644 \\
\hline $\mathrm{KCl}+\mathrm{K}_{2} \mathrm{SO}_{4}+\mathrm{SiO}_{2}{ }^{\mathrm{a}}$ & 690 \\
\hline $\mathrm{KCl}+\mathrm{K}_{2} \mathrm{SO}_{4}+\mathrm{K}_{2} \mathrm{CO}_{3}{ }^{\mathrm{a}}$ & 580 \\
\hline $\mathrm{KCl}+\mathrm{K}_{2} \mathrm{SO}_{4}+\mathrm{Fe}_{2} \mathrm{O}_{3}{ }^{\mathrm{a}}$ & 577 \\
\hline $\mathrm{KCl}+\mathrm{K}_{2} \mathrm{SO}_{4}+\mathrm{K}_{2} \mathrm{Si}_{4} \mathrm{O}_{9}{ }^{\mathrm{c}}$ & 650 \\
\hline $\mathrm{KCl}+\mathrm{K}_{2} \mathrm{SO}_{4}+\mathrm{KOH}^{\mathrm{a}}$ & 288 \\
\hline
\end{tabular}

Table 3. Composition of the investigated steel tubes

\begin{tabular}{|l|l|l|l|l|l|}
\hline Steel type & $\begin{array}{l}\text { Cr } \\
\text { (wt.\%) }\end{array}$ & $\begin{array}{l}\text { Ni } \\
\text { (wt.\%) }\end{array}$ & $\begin{array}{l}\text { Fe } \\
\text { (wt.\%) }\end{array}$ & Others (wt.\%) \\
\hline Iron & & & 100 & & \\
\hline $316 \mathrm{SS}$ & $16-18$ & $10-14$ & balance & $\mathrm{C}=0.08, \mathrm{Si}=0.75, \mathrm{Mn}=2, \mathrm{P}=0.045, \mathrm{~S}=0.03, \mathrm{Mo}=2.5$ \\
\hline TP347HFG & $17-20$ & $9-13$ & balance & $\begin{array}{l}\mathrm{C}=0.08, \quad \mathrm{Si}=0.75, \quad \mathrm{Mn}=2, \quad \mathrm{P}=0.04, \mathrm{~S}=0.03, \\
\mathrm{Nb}+\mathrm{Ta}=1\end{array}$ \\
\hline 3R69BT & 17.5 & 12.5 & balance & $\begin{array}{l}\mathrm{C}=0.03, \quad \mathrm{Si}=0.4, \quad \mathrm{Mn}=1.7, \quad \mathrm{P}=0.03, \quad \mathrm{~S}=0.015, \\
\mathrm{Mo}=2.2\end{array}$ \\
\hline
\end{tabular}

Table 4. Adhesion strength of different types of deposits. 


\begin{tabular}{|l|l|}
\hline Deposit type & $\begin{array}{l}\text { Adhesion } \\
\text { strength (kPa) }\end{array}$ \\
\hline $\begin{array}{l}\text { Biomass ash deposits, } \\
\text { current lab-scale } \\
\text { investigation }\end{array}$ & $1-350$ \\
\hline $\begin{array}{l}\text { Biomass ash deposits, full- } \\
\text { scale investigations }\end{array}$ & $20-250$ \\
\hline $\begin{array}{l}\text { Coal ash deposits, lab- } \\
\text { scale investigations }\end{array}$ & $35-350$ \\
\hline $\begin{array}{l}\text { Deposits from kraft } \\
\text { recovery boilers, lab-scale } \\
\text { investigations }\end{array}$ & $1000-16000$ \\
\hline
\end{tabular}

\section{Acknowledgements}

This work is part of the project, 'Flexible use of Biomass on PF fired power plants', funded by Energinet.dk through the ForskEL program, DONG Energy and DTU.

\section{References}

(1) Zbogar, A.; Frandsen, F.; Jensen, P. A.; Glarborg, P. Prog. Energy Combust. Sci. 2009, 35, $31-56$.

(2) Okoro, S. C.; Montgomery, M.; Frandsen, F. J.; Pantleon, K. Energy Fuels 2014, 28, 64476458.

(3) Frandsen, F. Ash formation, deposition and corrosion when utilizing straw for heat and power production; Technical University of Denmark, Department of Chemical Engineering, 2010. 
(4) Bashir, M. S.; Jensen, P. A.; Frandsen, F.; Wedel, S.; Dam-Johansen, K.; Wadenbäck, J. Energy Fuels 2012, 26, 5241-5255.

(5) Kaliazine, A.; Cormack, D.; Ebrahimi-Sabet, A.; Tran, H. J. Pulp Paper Sci. 1999, 25, 418424.

(6) Zhou, H.; Jensen, P. A.; Frandsen, F. J. Fuel 2007, 86, 1519-1533.

(7) Baxter, L. L. Biomass Bioenergy 1993, 4, 85-102.

(8) Jensen, P. A.; Frandsen, F. J.; Hansen, J.; Dam-Johansen, K.; Henriksen, N.; Hörlyck, S. Energy Fuels 2004, 18, 378-384.

(9) Moza, A. K.; Austin, L. G. Fuel 1981, 60, 1057-1064.

(10) Moza, A.; Shoji, K.; Austin, L. J. Inst. Energy 1980, 53, 17-19.

(11) Raask, E. VGB Kraftwerkstech 1973, 53, 248-254.

(12) Attig, R.; Barnhart, D. A laboratory method of evaluating factors affecting tube bank fouling in coal-fired boilers, in: Johnson, H. R.; Littler, D. J. The Mechanism of Corrosion by Fuel Impurities; Butterworth: London, 1963; pp 173.

(13) Conn, R.; Jones, M. Comparison of low-rank coal ash sintering characteristics with pilot plant ash fouling tendencies, in: Barrett, R. E. Third Engineering Foundation Conference on Slagging and Fouling Due to Impurities in Combustion Gases; Copper Mountain: Colorado, 1984; pp 207-228. 
(14) Cumming, I.; Joyce, W.; Kyle, J. J. Inst. Energy 1985, 58, 169-175.

(15) Yilu, S. Evaluating fouling and slagging characteristics of different Chinese coal ashes, in :Third engineering foundation conference on slagging and fouling due to impurities in combustion gases, in: Barrett, R. E. Third Engineering Foundation Conference on Slagging and Fouling Due to Impurities in Combustion Gases; Copper Mountain: Colorado, 1984; pp 557592.

(16) Piroozmand, F.; Tran, H.; Kaliazine, A.; Cormack, D. Strength of recovery boiler fireside deposits at high temperatures; Tappi Proceedings, 1998; pp 169-179.

(17) European Committee for Standardization, Solid biofuels - Method for the determination of ash melting behaviour - Part 1: Characteristic temperatures method, CEN/TS 15370-1:2006.

(18) Gupta, S.; Wall, T.; Creelman, R.; Gupta, R. Fuel Process. Technol. 1998, 56, 33-43.

(19) Hamzah, M.; Yeo, W.; Fry, A.; Inayat-Hussain, J.; Ramesh, S.; Purbolaksono, J. Eng. Failure Anal. 2013, 35, 380-386.

(20) Schmidt, D.; Schütze, M. Mater. Sci. Forum 2011, 696, 330-335.

(21) Yukitoshi, T.; Yoshikawa, K.; Daikoku, T.; Masuyama, F. J. Mater. Energy Syst. 1982, 4, 99-109.

(22) Zahs, A.; Spiegel, M.; Grabke, H. J. Corros. Sci. 2000, 42, 1093-1122.

(23) Okoro, S. C.; Kvisgaard, M.; Montgomery, M.; Frandsen, F. J.; Pantleon, K. Surf. Eng. 2016, 33, 428-432. 
(24) Israelsson, N.; Engkvist, J.; Hellström, K.; Halvarsson, M.; Svensson, J.; Johansson, L. Oxid. Met. 2015, 83, 29-53.

(25) Sabau, A.; Wright, I.; Shingledecker, J. Mater. Corros. 2012, 63, 896-908.

(26) Rizzi, M.; Guerrini, E.; Trasatti, S. Metall. Ital. 2012, 2, 29-35.

(27) Coleman, K.; Simms, N.; Kilgallon, P.; Oakey, J. Mater. Sci. Forum 2008, 595, 377-386.

(28) Grabke, H. J.; Meadowcroft, D. A working party report on guidelines for methods of testing and research in high temperature corrosion; European Federation of Corrosion: Belgium, 1995.

(29) Bashir, M. S.; Jensen, P. A.; Frandsen, F.; Wedel, S.; Dam-Johansen, K.; Wadenbäck, J.; Pedersen, S. T. Fuel Process. Technol. 2012, 97, 93-106.

(30) Wu, H.; Shafique Bashir, M.; Jensen, P. A. Full-scale ash deposition measurements at Avedøre Power Plant unit 2 during suspension-firing of wood with and without coal ash addition; Technical University of Denmark, Department of Chemical Engineering, 2012.

(31) Hansen, S. B. Model for Deposition Build-up in Biomass Boilers; Technical University of Denmark, 2015.

(32) Montgomery, M.; Jensen, S.; Borg, U.; Biede, O.; Vilhelmsen, T. Mater. Corros. 2011, 62, 593-605.

(33) Lindberg, D.; Niemi, J.; Engblom, M.; Yrjas, P.; Laurén, T.; Hupa, M. Fuel Process. Technol. 2016, 141, 285-298. 
(34) Montgomery, M.; Karlsson, A.; Larsen, O. H. Mater. Corros. 2002, 53, 121-131.

(35) van Lith, S. C. Release of inorganic elements during wood-firing on a grate; Technical University of Denmark, 2005.

(36) Bale, C.; Bélisle, E.; Chartrand, P.; Degterov, S.; Eriksson, G.; Hack, K.; Jung, I.; Kang, Y.; Melançon, J.; Pelton, A. Calphad 2009, 33, 295-311.

(37) Bale, C.; Chartrand, P.; Degterov, S.; Eriksson, G.; Hack, K.; Mahfoud, R. B.; Melançon, J.; Pelton, A.; Petersen, S. Calphad 2002, 26, 189-228.

(38) Arvelakis, S.; Jensen, P. A.; Dam-Johansen, K. Energy Fuels 2004, 18, 1066-1076.

(39) Sui, J.; Lehmusto, J.; Bergelin, M.; Hupa, M. Oxid. Met. 2014, 82, 437-456.

(40) Shinata, Y.; Nishi, Y. Oxid. Met. 1986, 26, 201-212.

(41) Pettersson, J.; Asteman, H.; Svensson, J.; Johansson, L. Oxid. Met. 2005, 64, $23-41$.

(42) Spiegel, M. Mater. Corros. 1999, 50, 373-393.

(43) Lee, S. Y.; McNallan, M. J. Corrosion 1991, 47, 868-874.

(44) Viklund, P.; Hjörnhede, A.; Henderson, P.; Stålenheim, A.; Pettersson, R. Fuel Process. Technol. 2013, 105, 106-112.

(45) Nielsen, H. P.; Frandsen, F. J.; Dam-Johansen, K. Energy Fuels 1999, 13, 1114-1121. 
(46) Packham, D. E. Theories of fundamental adhesion, In: da Silva, L. F. M.; Öchsner, A.; Adams, R. D. Handbook of Adhesion Technology; Springer: Berlin, 2011; pp 9-38.

(47) Iisa, K.; Lu, Y.; Salmenoja, K. Energy Fuels 1999, 13, 1184-1190.

(48) Sengeløv, L. W.; Hansen, T. B.; Bartolomé, C.; Wu, H.; Pedersen, K. H.; Frandsen, F. J.; Jensen, A. D.; Glarborg, P. Energy Fuels 2013, 27, 3283-3289.

(49) Borgwardt, R. H.; Bruce, K. R. AIChE J. 1986, 32, 239-246.

(50) Marsh, D.; Ulrichson, D. Chem. Eng. Sci. 1985, 40, 423-433.

(51) Henriksson, M.; Warnqvist, B. Ind. Eng. Chem. Process Des. Dev. 1979, 18, 249-254.

(52) Fielder, W.; Stearns, C.; Kohl, F. J. Electrochem. Soc. 1984, 131, 2414-2417.

(53) Jørgensen, T. L.; Livbjerg, H.; Glarborg, P. Chem. Eng. Sci. 2007, 62, 4496-4499.

(54) Fu, H.; Wang, X.; Wu, H.; Yin, Y.; Chen, J. J. Phys. Chem. C 2007, 111, 6077-6085.

(55) Baltrusaitis, J.; Cwiertny, D. M.; Grassian, V. H. Phys. Chem. Chem. Phys. 2007, 9, 55425554.

(56) Wu, H.; Bashir, M. S.; Jensen, P. A.; Sander, B.; Glarborg, P. Fuel 2013, 113, 632-643.

(57) Blomberg, T. Mater. Corros. 2006, 57, 170-175.

(58) Kiamehr, S.; Dahl, K. V.; Montgomery, M.; Somers, M. A. Mater. Corros. 2015, 66, 14141429. 
(59) Lehmusto, J.; Skrifvars, B.; Yrjas, P.; Hupa, M. Fuel Process. Technol. 2013, 105, 98-105.

(60) Ishitsuka, T.; Nose, K. Corros. Sci. 2002, 44, 247-263.

(61) Okoro, S. C.; Kiamehr, S.; Montgomery, M.; Frandsen, F. J.; Pantleon, K. Mater. Corros. 2017, 68, 499-514.

(62) Folkeson, N.; Jonsson, T.; Halvarsson, M.; Johansson, L.; Svensson, J. Mater. Corros. 2011, 62, 606-615.

(63) Dickinson, J. E.; Scarfe, C. M.; McMillan, P. J. Geophys. Res. 1990, 95, 15675-15681.

(64) Karlsson, S.; Jonsson, T.; Hall, J.; Svensson, J.; Liske, J. Energy Fuels 2014, 28, 3102-3109.

(65) Hurley, J. P.; Benson, S. A.; Energy Fuels 1995, 9, 19-30.

(66) Raask, E. Mineral impurities in coal combustion: behavior, problems, and remedial measures; Hemisphere Pub. Corp.: Washington, 1985.

(67) Janz, G. J.; Allen, C. B.; Downey, J. R.; Tomkins, R. Physical properties data compilations relevant to energy storage.I.Molten salts: Eutectic Data; Rensselaer Polytechnic Institute: New York, 1978. 